\title{
Problems Faced By MSMEs In Visakhapatnam District Of Andhra Pradesh State: A Rotated Factor Analysis.
}

\author{
N. Aruna, \\ Research Scholar,krishna University,Machilipatnam, DR. S.V. Ramana Rao, Area Chair - Finance, Siva Sivani \\ Institue of Management, Kompally, Secunderabad and Prof. D. Suryachandra Rao, Dean, Krishna University, \\ Machilipatnam.
}

\begin{abstract}
Small businesses often face a variety of problems related to their size. A frequent cause of bankruptcy is undercapitalization. This is often a result of poor planning rather than economic conditions. MSMEs in India face number of problems - absence of adequate and timely banking finance, non - availability of suitable technology, ineffective marketing due to limited resources, non availability of skilled manpower, Raw Material and frequent power cuts which leads to production problem. Presently, the Indian MSMEs are facing different types of problems. Hence the main purpose of the study is to analyze five major problems faced by MSMEs in Visakhapatnam District of Andhra Pradesh state. The study is empirical in nature as it is based on data collected with the help of structured schedule. An Industrial area in the district was selected and almost all the industries in that area were covered which include both registered and unregistered enterprises.
\end{abstract}

Keywords: Micro, Small, Medium Enterprises, Problems, Factor Analysis.

\section{INTRODUCTION}

Enterprises are a source for generation of employment in large numbers. Such enterprises are being broadly classified into:

i) Enterprises engaged in manufacture/production of goods pertaining to any industry and

ii) Enterprises engaged in providing/rendering of services.

II. CLASSIFICATION OF MSME SECTORS:

Based on the original investment in plant and machinery with regard to Manufacture/production units \& original investment in equipment with regard to Services units.

\begin{tabular}{|l|l|l|}
\hline & \multicolumn{1}{|l|}{$\begin{array}{l}\text { Investment in Plant and Machinery/ Equipment } \\
\text { (excluding land and Building }\end{array}$} \\
\hline & Manufacturing Enterprises & Services Enterprises \\
\hline Micro & Up to Rs. 25 lakhs & Up to Rs. 10 lakhs \\
\hline Small & $\begin{array}{l}\text { More than Rs.25 lakhs and } \\
\text { up to Rs. 5 crore }\end{array}$ & $\begin{array}{l}\text { More than Rs. 10 lakhs } \\
\text { and up to Rs. 2 crore }\end{array}$ \\
\hline Medium & $\begin{array}{l}\text { More than Rs.5 crore and } \\
\text { up to Rs. 10 crore. }\end{array}$ & $\begin{array}{l}\text { More than Rs.2 crore and } \\
\text { up to Rs. 5 crore }\end{array}$ \\
\hline
\end{tabular}

Small and large - scale enterprises are two legs of industrialization process of a country. Hence, small-scale enterprises are found in existence in every country. Small-scale enterprises have been given an important place in the framework of Indian planning since beginning both for economic and ideological reasons. Small-scale enterprises have now emerged as a dynamic and vibrant sector for the Indian economy in the recent years. Some of the major problems faced by these units are: Finance, Production, Marketing, Management and PreCommencement of business Problems.

\section{REVIEW OF LITERATURE}

Dr. Ashok Kumar Panigrahi of Shirpur (December 2012): In his paper he has mentioned about various issues and problems of MSMEs and emphasized on the Risks faced by MSMEs. He said that in the present scenario, where profits are derived mainly from trading in the market, one can no longer afford to avoid measuring risk and managing its implications thereof. It was said that to the extent of SME entity takes risk consciously, anticipates adverse change and hedges accordingly it becomes a source of competitive advantage as 
it can offer its product at a better price than its competitors. He said that what can be measured can also be managed. It should be clearly understood that risk mitigation efforts are more important and vital than capital allocation against inadequate risk management system.Dr. K.K.Patra, C.Panigrahi, (March 2013), Need Based Funding to Micro, Small and Medium Enterprise Sectors: A Particle Approach: the paper highlighted the need based funding on Micro, Small and Medium enterprise sectors (MSMEs) with particular reference to manufacturing sectors in India. It was said that no country whether large or small, developed or developing, can underestimate the immense potential and contribution of small enterprises.Dr. Padmasani, S. Karthika (2013), A study on Problems and Prospects of Micro, Small and Medium Scale Enterprise in Textile Exports with special reference to Tirupur and Coimbatore District. This paper has examined the problems of MSMEs in the era of global economy and also has identified the factors affecting MSMEs. A study was also made on the socioeconomic conditions of MSMEs. The survey revealed that the problems can be overcome if MSMEs get involved in standardization of the business process, and can also adopt latest technology to improve the productivity. It was said that banks can support the industry by providing the credit facilities at low interest rate and Government and Institutions relating to Small and Medium Scale industries should take effective measures to improve the export performance of MSMEs in order to develop economy. The study covered the districts of Tirupur and Coimbatore district.Jaskaran Singh and Davinder Singh (Jan. 2014). The study made an attempt to identify the problems related to finance of MSMEs. Based on the study the researcher concluded that the growth of the MSMEs sector at a healthy rate is crucial for overall growth of the industry. However, lack of proper financial facilities is the barrier of better performance. It is said that these sectors depend much of their initial capital on internal sources as they have accessibility problems in getting external debt or equity financing. Even if they are offered with debts, they will be charged with high rates of interest as smaller enterprises are perceived to be more risky and more likely to fail in repayment. The study has presented four key issues under financial management namely: shortage of own finance via bank loans, Government subsidies, relief in taxes etc.

Sangitha G Patel, Dr. P.T. Chadudhari, (April 2014) Problems of Small Scale Industries in India. This paper dealt with Problems of S.S.I in India such as Problem of skilled manpower, Inadequate credit assistance, Irregular supply of raw material, Absence of organized marketing, Lack of Machinery \& equipment and Absence of adequate infrastructure, competition from large-scale units and imported articles. All these problems were discussed in general, but not relating to any particular State or Region.Nishanth P, Dr. Zakkariya K.A. (May 2014)), discussed about the problems faced by the MSMEs sectors in India due to certain constraints like absence of adequate and timely supply of bank fiancé, difficulties in procuring raw materials, marketing and distribution challenges and non availability of suitable technology. This study tried to identify the various barriers faced by these units in raising finance and also tried to indentify the various sources of finance other than banks. The study was empirical in nature which collected data from 200 MSMEs in Kozhikode district of Kerala by using systematic random sampling methods. The study concluded that the growth and development of MSMEs can be ensured by initiating actions by government and banks for arranging the MSMEs to avail more credit by way of reducing the barriers perceived by the entrepreneurs. It also attempted to submit some recommendations to enhance the overall credit accessibility to MSMEs sector.

Dr. A.S. Shiralashetti (July - Aug.2014), prospects \& Problems of MSMEs in India. The researcher in his paper examined the growth and performance MSMEs and its contribution to GDP. The study also analyzed the problems faced by MSMEs located in Dharwad district of Karnataka State. Both primary and secondary data was used. The growth and performance of MSMEs was covered for a period from 2001-2010. The researcher concluded that inorder to empower the MSME sector it is necessary to support these sectors, need to educate and empower them to make optimum utilization of resources, both human and economic inorder to achieve success. It was said that these sectors need to be informed about the latest developments which are taking place globally and should be helped to acquire skills necessary to keep pace with the global developments.

Updesh Khinda, Gagandeep Kaur, Dr. Nacchattar Singh \& Dr. H.S. Sandhu (April 2014), They made a study on the MSME Act, 2006 and its impact, problems \& Challenges of MSMEs in India were high lightened. The Methodology adopted by them was secondary data and the study covered a period of 2001-02 and 2013-14. In the analysis they proved that MSMEs Sector have shown a tremendous improvement in terms of Employment, growth rate and productivity after the implementation of the Act. Hence it was inferred that MSMEs Act 2006, has a strong positive effect on Micro, Small and Medium Enterprises. This paper was concluded by saying that MSMEs face cut throat competition from all over the world in different product categories. To cope up with this government of India has made many efforts especially through MSME Act, 2006 to enhance the competitiveness, productivity and growth of MSMEs in India. It was said that Government of India has provided various facilities like Entrepreneurship Training, Marketing Access, credit facilities, protection, financial subsidies and concessions to MSMEs etc. In spite of all the measurements taken by Government it was concluded that skill MSMEs Sectors faces certain problems specifically related to poor supply of raw material rising cost of inputs, lack of adequate marketing facilities, obsolete technology, lack of 
Entrepreneurship Education ignorance of government's policies and plans on the part of entrepreneur based on the above study, I felt a need to study whether MSMEs in Andhra Pradesh faces similar types of problems.

Dr. Mateen Ahmed Siddiqui (2015) explored the specific challenges which were encountered by the MSME sector. He analyzed the data collected with the help of structured questionnaire by using ANOVA tool to found that the major problems faced by MSMEs were in the form of marketing the products and shortage of working capital. The study reflected that excessive competition in the market, weak market demand, marketing of goods is the marketing variables affecting MSMEs. On the other hand, the shortage of working capital, high cost of borrowing, unavailability of credit, and difficulty of receiving amount from debtors are the key financial variables. The study also emphasized that availability of long term finance is not a bigger problem than arrangement of working capital is and secondly the repayments of financial liabilities are worrying and disappointing due to low paying capacity and insignificant sales.

\section{MATERIALS AND METHODS:}

From the review it is found that Micro, Small and Medium Enterprises play a dominant role in Indian Economy. But there are various problems faced by these enterprises (Ashwini K, July - 2012) due to which the growth of the enterprises is affected (Dr. Padmasani, S. Karthika (2013), in turn affecting the growth of the country. Though there are various studies done on the problems, the researcher felt a gap in respect to the problems faced by MSMEs in Visakhapatnam district of Andhra Pradesh. Hence the researcher felt a need to study the problems faced by MSMEs. The present study focused on the analyses and interpretation of problems faced by MSMEs in Visakhapatnam district in five areas by using rotated factor analysis technique.

\section{METHODOLOGY\& HYPOTHESIS}

Both primary and secondary data are used in the study. The study is empirical in nature as it is based on data collected with the help of schedule. The study focused the collection of data from one region in Andhra Pradesh. A simple random sampling technique was used and a highly industrial area was selected and almost all the industries in that area were covered. The data was collected from 150 enterprises, which is not less than many other conjoint studies, for example, in studies of small scale industries, with sample size 95 (B. Deevena Margaret April 1994), 100 (R. Sathru Sangara Velsamy, Dec. 2014) and 254 (Siddiq. I, June 2013).The sample covered micro, small and medium enterprises in that area, though there are registered or unregistered. The data collected was run through SPSS software and factor analysis was used to study the problems faced by these sectors in five different areas.

Ho: There is no significance difference between the problems faced by MSMEs in Visakhapatnam district.

H1: There is significance difference between the problems faced by MSMEs in Visakhapatnam district.

\section{A FACTOR ANALYSIS}

Factor analysis is a technique which helps to reduce the number of variables and also to detect structure in the relationships between variables, that is to classify variables. Thus factor analysis is applied as a data reduction or structure detection method (the term factor analysis was first introduced by Thurstone, (1931).In order to test the validity of the data for factor analysis KMO (Kaiser Meyer Olkin) and Bartlett's test of Sphericity was conducted. This test is an indicator to know how well the sample data is suited for factor analysis. It is the ratio of the sum of the squared correlations for all variables in the analysis to the squared correlations of all variables plus the sum of the squared partial correlations for all variables. The denominator of this ratio increases with the variation that is unique to pairs of variables (partial correlations), making the value of KMO less than one. These measures suggest that values of 0.9 or higher are great and values below 0.5 are unacceptable. The use of KMO and Bartlett's test of sphericity is essential to measure sample adequacy for using factor analysis.

TABLE 1

KMO AND BARTLETT'S TEST

\begin{tabular}{|l|l|l|}
\hline Kaiser Meyer Olkin & $\begin{array}{l}\text { Measure of Sampling } \\
\text { Adequacy }\end{array}$ & 0.759 \\
\hline Bartlett's test of Sphericity & Approx. Chi-Square & 135.806 \\
\hline & DF & 10 \\
\hline & Sig & .000 \\
\hline
\end{tabular}


The factor analysis is used to study the problems faced by MSMEs in Visakhapatnam district. These problems are studied in five areas.

1. Finance Problems

2. Production Problems

3. Marketing problems

4. Managerial problems

5. Pre - Commencement of business Problems

Finance problems contains 15 variables, Production problems contains 4 sub problems namely Raw Material, Power, labour and Technology. On the whole 17 variables are covered in all the four sub problems. 11 variables are covered in marketing problems, 5 variables are covered in managerial problems and 7 variables are covered in Pre-Commencement of business problems. Hence on the whole 55 variables are covered in five areas.

55 variables were run into SPSS software and the results showed only 33 variables. Which are as follows:

\title{
I FINANCE PROBLEMS:
}

1. Grant of loan (GL)

2. Documentation (D)

3. Security (S)

4. Maintain books of accounts (MBA)

5. Budgeting (B)

6. Payment of VAT (V)

7. Payment of CST (C)

8. Payment of Excise duty (ED)

9. Payment of Custom duty (CD)

10. Problem for claiming Input Tax Credit (ITC)

11. Factoring $(\mathrm{F})$

12. Allowing credit to customers (ACC)

13. Slow collection of debts (SCD)

14. Grant of subsidy (GS)

15. High discount allowed (HDA)

\author{
(i) Raw Material: \\ 1. Shortage of availability of Raw Material (SRM) \\ 2. High cost of Raw Material (HRM) \\ 3. Increase in ordering cost due to less quantity ordered (OC) \\ 4. Import of Raw Material (IRM) \\ 5. Problems in storage of Raw Material (STRM) \\ (ii) Power Problems: \\ 1. Power cut (PC) \\ 2. High cost of alternate power (diesel for generator) (AP) \\ 3. Power holiday $(\mathrm{PH})$ \\ 4. High expenditure on power consumption (EPC) \\ (iii) Labour Problems; \\ 1. High cost of skilled labour (HSL) \\ 2. Non availability of skilled labour (NASL) \\ 3. Frequent absenteeism of labour (FAL) \\ 4. More idle time spent by labour (ITL) \\ (iv) Technology Problem: \\ 1. Non Availability of Machinery (NAM) \\ 2. Under utilization (UU)
}

II PRODUCTION PROBLEMS:

III PRE- COMMENCEMENT OF BUSINESS PROBLEM:

1. Seeking permit from environment department (SPED)

2. Registration (R)

3. Tax related problems (TP) 
TABLE 2

COMMUNALITIES

\begin{tabular}{|c|c|c|c|}
\hline S.No. & Variables & Initial & Extraction \\
\hline 1 & grant & 1.000 & .881 \\
\hline 2 & documen & 1.000 & .840 \\
\hline 3 & security & 1.000 & .852 \\
\hline 4 & books & 1.000 & .863 \\
\hline 5 & budget & 1.000 & .854 \\
\hline 6 & vat & 1.000 & .927 \\
\hline 7 & cst & 1.000 & .911 \\
\hline 8 & excise & 1.000 & .936 \\
\hline 9 & cusdut & 1.000 & .913 \\
\hline 10 & inputax & 1.000 & .847 \\
\hline 11 & facting & 1.000 & .727 \\
\hline 12 & cretoc & 1.000 & .845 \\
\hline 13 & slowdet & 1.000 & .753 \\
\hline 14 & subsidy & 1.000 & .730 \\
\hline 15 & highdis & 1.000 & .901 \\
\hline 16 & shorage & 1.000 & .845 \\
\hline 17 & highct & 1.000 & .669 \\
\hline 18 & ording & 1.000 & .843 \\
\hline 19 & imporrm & 1.000 & .760 \\
\hline 20 & storarm & 1.000 & .682 \\
\hline 21 & powcut & 1.000 & .844 \\
\hline 22 & altertiv & 1.000 & .920 \\
\hline 23 & holiday & 1.000 & .934 \\
\hline 24 & highexp & 1.000 & .886 \\
\hline 25 & skilled & 1.000 & .785 \\
\hline 26 & nonaval & 1.000 & .914 \\
\hline 27 & absent & 1.000 & .877 \\
\hline 28 & idltime & 1.000 & .792 \\
\hline 29 & navimac & 1.000 & .701 \\
\hline 30 & under & 1.000 & .885 \\
\hline 31 & evirn & 1.000 & .852 \\
\hline 32 & registr & 1.000 & .816 \\
\hline 33 & $\operatorname{tax}$ & 1.000 & .693 \\
\hline
\end{tabular}

Extraction Method: Principal Component AnalysisTable 4.2 shows the communalities of 31 variables out of whose initial values are 1 and the extraction values are more than 0.5 .

TABLE 3: TOTAL VARIANCE EXPLAINED

\begin{tabular}{|l|l|l|l|l|l|l|l|l|l|}
\hline \multirow{2}{*}{$\begin{array}{l}\text { Comp } \\
\text { onent }\end{array}$} & \multicolumn{3}{|c|}{ Initial Eigen values } & \multicolumn{3}{c|}{$\begin{array}{c}\text { Extraction Sums of Squared } \\
\text { Loadings }\end{array}$} & \multicolumn{3}{c|}{$\begin{array}{c}\text { Rotation Sums of Squared } \\
\text { Loadings }\end{array}$} \\
\cline { 2 - 10 } & Total & $\begin{array}{c}\text { \% of } \\
\text { Varian } \\
\text { ce }\end{array}$ & $\begin{array}{c}\text { Cumula } \\
\text { tive \% }\end{array}$ & Total & $\begin{array}{c}\text { \% of } \\
\text { Variance }\end{array}$ & $\begin{array}{c}\text { Cumul } \\
\text { ative } \\
\%\end{array}$ & Total & $\begin{array}{c}\text { \% of } \\
\text { Varian } \\
\text { ce }\end{array}$ & $\begin{array}{c}\text { Cumulati } \\
\text { ve \% }\end{array}$ \\
\hline 1 & 7.310 & 22.151 & 22.151 & 7.310 & 22.151 & 22.151 & 5.568 & 16.874 & 16.874 \\
\hline 2 & 5.489 & 16.634 & 38.785 & 5.489 & 16.634 & 38.785 & 4.391 & 13.305 & 30.179 \\
\hline 3 & 3.816 & 11.564 & 50.349 & 3.816 & 11.564 & 50.349 & 3.463 & 10.493 & 40.672 \\
\hline 4 & 3.107 & 9.415 & 59.764 & 3.107 & 9.415 & 59.764 & 3.127 & 9.475 & 50.147 \\
\hline 5 & 2.217 & 6.717 & 66.481 & 2.217 & 6.717 & 66.481 & 2.910 & 8.817 & 58.965 \\
\hline 6 & 1.797 & 5.444 & 71.926 & 1.797 & 5.444 & 71.926 & 2.488 & 7.539 & 66.503 \\
\hline 7 & 1.353 & 4.098 & 76.024 & 1.353 & 4.098 & 76.024 & 2.451 & 7.427 & 73.930 \\
\hline 8 & 1.345 & 4.077 & 80.101 & 1.345 & 4.077 & 80.101 & 1.584 & 4.799 & 78.729 \\
\hline 9 & 1.045 & 3.168 & 83.269 & 1.045 & 3.168 & 83.269 & 1.498 & 4.539 & 83.269 \\
\hline 10 & .999 & 3.027 & 86.295 & & & & & & \\
\hline 11 & .758 & 2.298 & 88.593 & & & & & & \\
\hline
\end{tabular}


Problems Faced By Msmes In Visakhapatnam District Of Andhra Pradesh

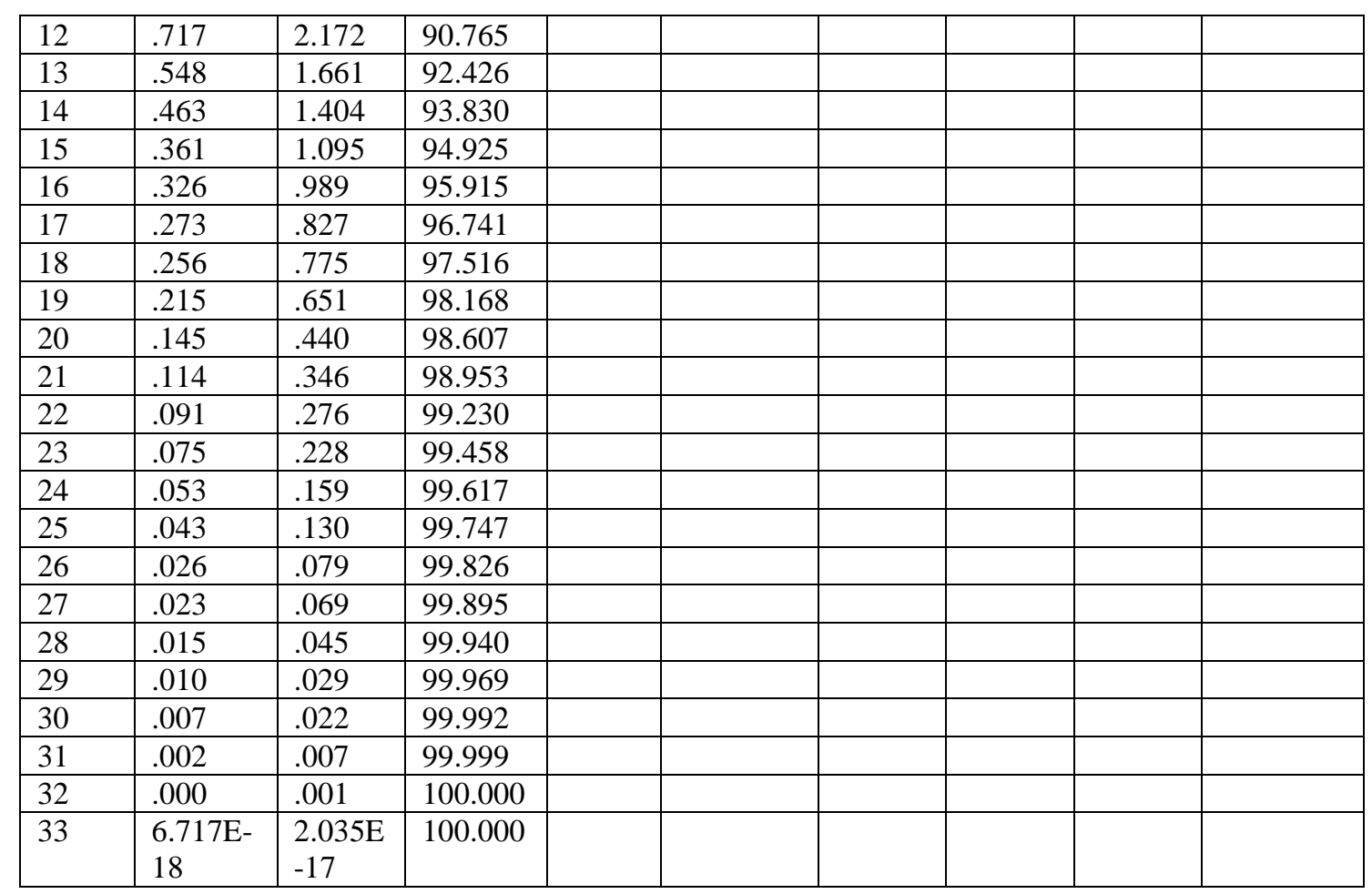

Extraction Method: Principal Component AnalysisPrincipal Component Analysis was used to extract the variables and out of 33 variable extracted only 9 variables have Initial Eigen values more than 1 . The cumulative percentage of these variables is shown as 83.269.

TABLE AROTATED FACTOR LOADINGS

\begin{tabular}{|c|c|c|c|c|c|c|c|c|c|c|c|}
\hline \multirow{2}{*}{$\begin{array}{l}\text { S. } \\
\text { No }\end{array}$} & \multirow{2}{*}{$\begin{array}{l}\text { VARLABL } \\
\text { ES }\end{array}$} & \multicolumn{9}{|c|}{ FACTOR } & \multirow{2}{*}{$\begin{array}{l}\text { COMDMUN } \\
\text { ALITY }\end{array}$} \\
\hline & & 1 & 2 & 3 & 4 & 5 & 6 & 7 & 8 & 9 & \\
\hline 1 & grant & 252 & 879 & -164 & .074 & -029 & -032 & -081 & .066 & -.004 & 881 \\
\hline 2 & documen| & 118 & 811 & 276 & 203 & 147 & -.094 & -130 & 058 & .010 & 840 \\
\hline 3 & security & -120 & -039 & 122 & -025 & 170 & -8.83 & $-.03 ?$ & .085 & -.059 & 852 \\
\hline 4 & books & 198 & .754 & 358 & 203 & -198 & 031 & -113 & 002 & 180 & 863 \\
\hline 5 & budget & 529 & 014 & 383 & -.078 & -.435 & 041 & -228 & 184 & 378 & 854 \\
\hline 6 & vat & 938 & -.060 & .050 & -.023 & -.095 & 096 & -105 & -093 & -.053 & 927 \\
\hline 7 & cst & 908 & -.050 & .079 & 252 & -.075 & .057 & -.061 & -.035 & -012 & 911 \\
\hline 8 & excise & 923 & -063 & 130 & 149 & -.098 & .042 & .004 & -166 & -044 & 936 \\
\hline 9 & cusdut & 891 & -109 & .015 & 017 & -175 & .034 & -.038 & 264 & .061 & 913 \\
\hline 10 & inputax & .727 & 121 & 362 & -.093 & -.009 & -.018 & -076 & 396 & 013 & 847 \\
\hline 11 & facting & 384 & 199 & -159 & -256 & -.642 & .007 & .075 & 176 & -019 & 727 \\
\hline 12 & cretoc & -323 & -124 & 327 & -.071 & 023 & .777 & -.008 & -087 & .043 & 845 \\
\hline 13 & slowdet & 141 & -764 & 242 & .000 & 137 & -.097 & -111 & -114 & 194 & .753 \\
\hline 14 & subsidy & -144 & .761 & -190 & 211 & -097 & .040 & .165 & .084 & -.070 & .730 \\
\hline 15 & highdis & 308 & 169 & 238 & 358 & .042 & .018 & 134 & -752 & -.082 & 901 \\
\hline 16 & shorage & -166 & 239 & -202 & 322 & .781 & .002 & .045 & .006 & .060 & 845 \\
\hline 17 & highct & 159 & 287 & .069 & 078 & .636 & 191 & 324 & -.069 & -017 & 669 \\
\hline 18 & ording & -123 & 282 & 366 & -108 & .732 & 013 & 253 & .036 & .039 & 843 \\
\hline 19 & imporm & 157 & -279 & 068 & -254 & -.012 & -708 & 183 & 146 & 179 & 760 \\
\hline 20 & storam & -300 & 373 & 275 & .044 & 510 & .054 & .095 & 193 & -256 & .682 \\
\hline 21 & powcut & -.084 & -.068 & 817 & -.067 & 256 & 174 & 184 & -174 & -.023 & 844 \\
\hline 22 & altertiv & 266 & 014 & .867 & 046 & 224 & -.008 & .098 & 183 & .028 & 920 \\
\hline 23 & holiday & -110 & -087 & 810 & -.094 & 433 & .050 & 227 & -.086 & -.010 & 934 \\
\hline 24 & highexp & -079 & -.051 & .669 & -.078 & 432 & 478 & 068 & 060 & .018 & 886 \\
\hline 25 & skilled & 207 & -.049 & 193 & 811 & 114 & -.024 & 155 & -078 & 043 & 785 \\
\hline 26 & nonaval & 111 & .126 & -017 & 905 & 171 & 101 & -076 & -.081 & -121 & 914 \\
\hline 27 & absent & .155 & -.031 & .083 & 866 & -.022 & 162 & -226 & -108 & -.075 & 877 \\
\hline 28 & idltime & -.089 & 221 & 403 & 595 & 161 & -.039 & .145 & -051 & -409 & 792 \\
\hline 29 & navimac & -011 & 340 & 136 & -118 & 149 & -180 & .669 & -.079 & 210 & 701 \\
\hline 30 & under & 329 & -194 & 084 & 211 & -.097 & .059 & -285 & -154 & -755 & 885 \\
\hline 31 & over & .078 & .005 & 300 & .062 & .092 & -040 & -857 & 087 & -.001 & 852 \\
\hline 32 & registr & 399 & -075 & .051 & .046 & -108 & .075 & -533 & -257 & 529 & 816 \\
\hline 33 & $\operatorname{tax}$ & -254 & .066 & .119 & .174 & .106 & -132 & .120 & .683 & 265 & .693 \\
\hline
\end{tabular}

Extraction Method: Principal Component Analysis.Rotation Method: Varimax with Kaiser Normalization.

Rotation converged in 10 iterations. 
In order to reduce the number of factors and enhance the interpretability, the factors were rotated, since the rotation increases the quality of interpretation of the factors. Though there are various methods for rotation in order to obtain simple structure of the data, the varimax rotation is one such method which is used in order to obtain better result for interpretation which is shown in the above table 4 . It shows that 9 factors were extracted. 0.50 factor loading was used as a cut-off point, therefore the surviving variables with factor loadings of 0.50 or higher are considered further for interpretation and naming. The interpretation and naming of factors implied that the remaining or surviving variables with high factor loadings and common conceptual meanings were grouped together to form a genuine independent factor.

TABLE 5: CLUSTERING OF VARIABLES INTO FACTORS

\begin{tabular}{|c|c|c|}
\hline FACTOR & VARIABLES & $\begin{array}{l}\text { ROTATED FACTOR } \\
\text { LOADING }\end{array}$ \\
\hline \multirow[t]{5}{*}{1} & VAT & 0.938 \\
\hline & CST & 0.908 \\
\hline & Excise duty & 0.923 \\
\hline & Custom duty & 0.891 \\
\hline & $\begin{array}{l}\text { Problem for claiming Input tax } \\
\text { credit }\end{array}$ & 0.727 \\
\hline \multirow[t]{4}{*}{2} & Grant of subsidy & 0.761 \\
\hline & Maintain books of accounts & 0.754 \\
\hline & Grant of loan & 0.879 \\
\hline & Documentation & 0.811 \\
\hline \multirow[t]{4}{*}{3} & Power cut & 0.817 \\
\hline & Power holiday & 0.810 \\
\hline & $\begin{array}{l}\text { High expenditure on power } \\
\text { consumption }\end{array}$ & 0.669 \\
\hline & High cost of alternative power & 0.867 \\
\hline \multirow[t]{4}{*}{4} & more idle time spent by labour & 0.595 \\
\hline & High cost of skilled labour & 0.811 \\
\hline & Non - availability of skilled labour & 0.905 \\
\hline & Frequent absenteeism of labour & 0.866 \\
\hline \multirow[t]{4}{*}{5} & Shortage of Raw Material & 0.781 \\
\hline & Increase in ordering cost & 0.732 \\
\hline & Problem in storage of Raw Material & 0.510 \\
\hline & High cost of Raw Material & 0.636 \\
\hline 6 & Allowing credit to customers & 0.777 \\
\hline 7 & Non - availability of Machinery & 0.669 \\
\hline 8 & $\begin{array}{l}\begin{array}{l}\text { Pre-commencement tax } \\
\text { problems }\end{array} \\
\end{array}$ & 0.683 \\
\hline 9 & Registration & 0.529 \\
\hline
\end{tabular}

Table 5 shows the clustering of variables whose values are greater than 0.5 inorder to group them into factors and name them as factor 1 to factor 9.As per table .3: factor 1 (Finance Problems relating to Tax) accounts for 22.15 percent of the total variance and is derived from five variables, namely: VAT (0.938), CST (0.908), excise duty (0.923), Custom Duty (0.891) and problem relating to input tax credit (0.727). All these variables refer to tax problems, hence of all the five problems studied by the researcher it is found from the analysis that MSMEs are facing tax problems. Factor 2: (Finance Problems) accounts to 16.348 percent of the total variance and is derived from four variables, namely; maintenance of books of accounts (0.754), grant of loan (0.879), Documentation (0.811) and allowing credit to customers (0.777). All the variables in factor 2, are problems relating to finance. Factor 3: (Power Problems) accounts to 11.564 percent of the total variance and is derived from four variables, namely: Power cut (0.817), Power holiday (0.810), High expenditure on power consumption (0.683) and High cost of alternative power (0.867). All the four variables are relating to Power problems. Factor 4: (Labour Problems) accounts to 9.415 percent of the total variance and is derived from four variables, namely: idle time spent by labour (0.595), high cost of skilled labour (0.811), Non-availability of skilled labour (0.905) and frequent absenteeism of labour (0.866). All the three variables are representing the Problems relating to labour. It shows that MSMEs are seriously facing Problems relating to labour. It ranked 3. Factor 5: (Raw Material Problems) accounts to 6.717 percent of the total variance and is derived from four variables, namely: shortage of Raw Material (0.781), Increase in ordering cost due to less quantity ordered 
(0.732), Problem in storage of Raw Material (0.510) and High cost of Raw Material. All the four problems are relating to Raw Material problem. It shows that the MSMEs are not only facing problems relating to finance and Labour but also problem relating to Raw Material.

Factor 6: (Debtors Problems) accounts to 5.444 percent of the total variance and is derived from only one variable, namely allowing credit to customers $(0.777)$. This variable represents the problem relating to Debtors.

Factor 7: (Technology Problems) accounts to 4.098 percent of the total variance and is derived from one variable, namely Non- Availability of Machinery (0.669). It shows that these enterprises are facing problems relating to production.

Factor 8: (Pre commencement tax related Problems) accounts to 4.077 percent of the total variance and is derived from only one variable, namely: problem relating to tax before commencement of business $(0.683)$. This variable is relating to Pre commencement Problems.

Factor 9: (Registration Problems) this factor accounts to 3.168 percent of the total variance and is derived from only one variable, namely: Registration before commencement of business (0.529). This variable is only one variable which is relating to Pre-commencement problems.

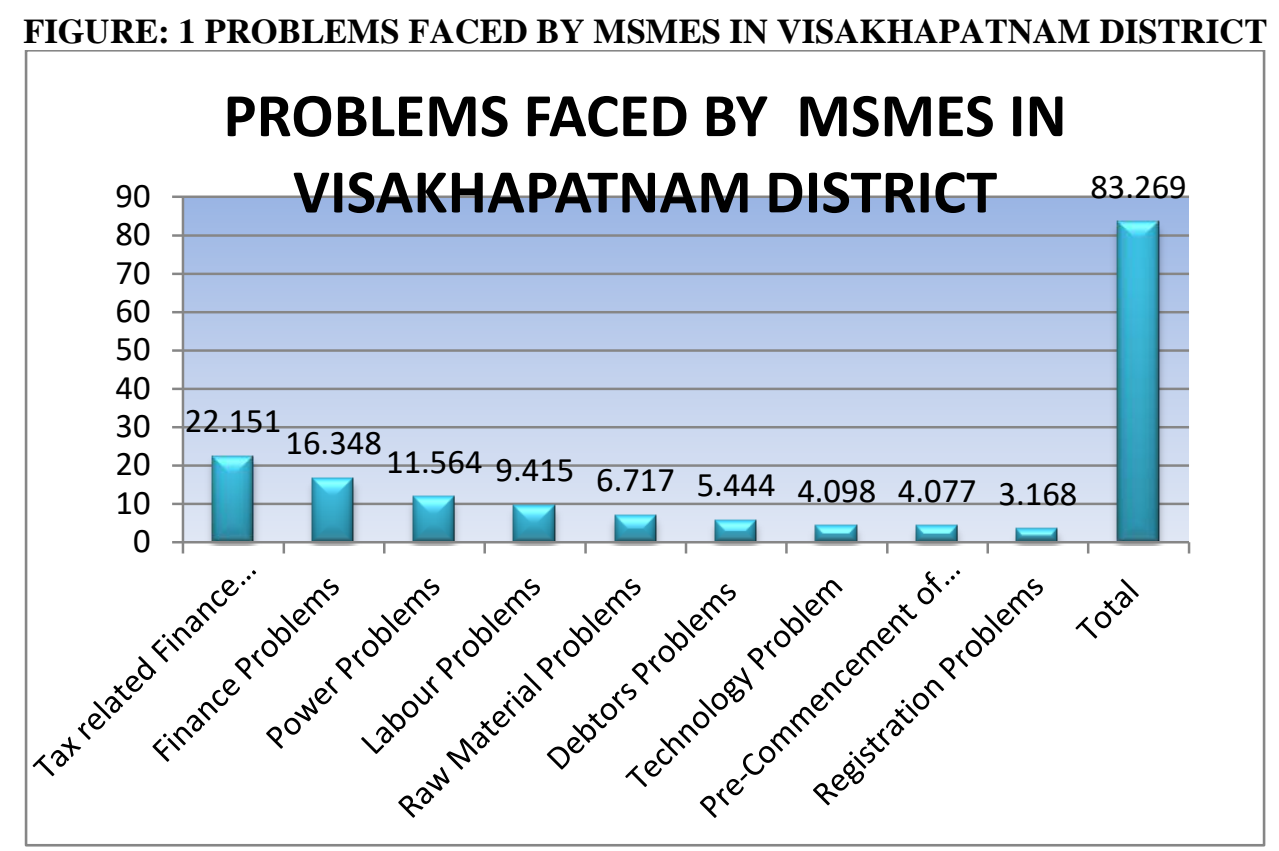

The above chart explains nine problems faced by MSMEs in Visakhapatnam district of Andhra Pradesh State.

VII.

\section{CONCLUSION}

The main findings of the study have generated some important factors relating to problems faced by MSMEs in Visakhapatnam district of Andhra Pradesh. It concludes that Tax is a major problem faced by these enterprises which is derived in factor 1. All the Tax related variables are extracted under factor 1, namely: problems relating payment of VAT, CST, Excise duty, Custom duty and problem for claiming input tax credit. Due to lack of funds they are unable to pay various taxes. Hence the study revealed that tax related Finance Problem is the major factor which these sectors are facing with. The second highest problem faced by these enterprises is relating to Finance. It is derived in factor 2. The variables derived in this factor are grant of subsidy, maintenance of books, documentation, and grant of loan. . All these four variables are derived in factor 2. This shows that all the variables relating to finance are clustered in factor 2 . Factor 1 also shows that these sectors are facing finance problems but purely relating to tax. It means that MSMEs are facing serious problem relating to Finance. The third highest problem faced by these enterprises is relating to Power. It is derived in factor 3 which has four variables. The variables derived in this factor are Power cut, Power holiday, high expenditure on power consumption and High cost of alternative power. All these four variables are representing the problem relating to Power. Hence it is proved that MSMEs are facing problems relating to Power, which in turn affects their production. The use of alternative power arises since there is acute power cut, power holiday and high consumption of power. The fourth highest problem faced by these enterprises is relating to labour. This is derived in Factor 4. The variables derived in this factor are problems relating to idle time spent by labour, high cost of skilled labour, non availability of skilled labour and frequent absenteeism of labour. All 
these four variables are representing the labour problems It shows that MSMEs are facing labour problem which in turn effects production along with power.The fifth problem faced by these enterprises is relating to Raw Material which is derived in Factor 5. The variables derived in this factor are shortage of Raw Material, Increase in ordering cost, problem in storage of Raw Material and High cost of Raw Material. This shows that the fifth problems faced by these enterprises are relating to Raw Material, which in turn affects the production along with power problems and labour problems. This proves that one of the major problems faced by these sectors is production. The sixth problems faced by these sectors is relating to debtors. It is derived in factor 6 . There is only one variable derived in this factor which is problems relating to allowing credit to customers. This shows that by allowing credit to customers MSMEs are facing problem. This problem is also part of Finance Problem.

The Seventh problem faced by MSMEs is relating to Technology. This is derived in Factor 7. There is only one variable derived in factor 7 relating to technology which is Non availability of Machinery. This variable is representing the problem relating to technology. The technology problem also affects the production.

The eight problem faced by these sector is relating to Pre commencement of business. The variable derived in this factor 8 is tax problem before commencement of business. This variable is representing the problem before commencement of business. This variable is the only variable which is representing the problem relating to precommencement of business. The ninth problem faced by these enterprises is relating to Registration of business. This is derived in factor 9. Only one variable is derived which is Registration. It shows that before commencement of business these sectors are facing problems relating to tax and also Registration. From the above findings it can be concluded that though the researcher has conducted a study on five areas of problems namely, finance, production, marketing, management and pre-commencement of business. The results proved that the MSMEs in Visakhapatnam district are facing two major problems. 1. Relating to Finance and 2. Relating to Production. In Production the major problem faced by them are relating to power and next is relating to labor and then comes the problems relating to Raw Material and a minor problem relating to technology and Pre-commencement of business. The other two problems of the study are not disclosed in the analysis. It means that MSMEs are not facing any problem relating to marketing and management. So Finance is the major problems and next is the Production problems.. It proves that all the MSMEs are facing problems in two major areas, hence the Null Hypothesis is accepted.

\section{REFERENCES:}

[1] Dr. Ashok Kumar Panigrahi, December (2012), Risk Management in Micro, Small and Medium Enterprises in India: A critical Appraisal, Asia Pacific Journal of Marketing and Management review, Volume 1 (4), ISSN 2319-2836, pp.12-34.

[2] Dr. Padmasani \& S. Karthika, (Oct. - Dec. 2013), A Study on Problems and Prospects of Micro, small and Medium Scale Enterprise in Textile Exports with special reference to Tirupur and Coimbatore District, IJAMBU, Volume 1, Issue 1, ISSN 2384-1382 (Online), pp. 55-60.

[3] Jaskaran Singh and Davinder Singh, (Jan. 2014), Problems related to financing of Small Firms in India, International Journal of Innovative Research \& Development, Vol. 3, Issue1, ISSN: 2278 - 2011 (online), pp.317-321

[4] Sangita G. Patil, Dr. P.T. Chaudhari, (April-2014), Problems of Small Scale Industries in India, International journal of Engineering and Management Research, Vol.4, Issue-2, ISSN No. 2250-0758; pp. $19-21$.

[5] Nishanth P, Dr. Zakkariya K.A, (May 2014), Barriers faced by Micro, Small \& Medium enterprises in raising finance, Abhinav National Monthly Referred Journal of Research in Commerce and Management; Vol.3, Issue 5 ISSN - 2277-1166; pp: 39-46.

[6] Dr. A.S. Shiraleshatti, ( July-August 2014) Prospects and Problems of MSMEs in India- A study, International Journal of in Multidisciplinary and Academic Research (SSIJMAR), Vol. 1, No. 2, ISSN 2278-5973, pp. 1-7.

[7] Updesh Khinda, Gagandeep Kaur, Dr. Nacchattar Singh \& Dr. H.S. Sandhu, (April 2014), MSMED Act, 2006 - A Promotional Tool for MSMEs in India ,Journal of Business Management \& Social Sciences Research (JBM\&SSR) ISSN No. 2319-5614, Volume 3, No.4, pp. 10-25.

[8] Dr. Mateen Ahmed Siddiqui, (April 2015), "Operational Problems of Micro Small and Medium Enterprises," International Journal in Management and Social Science, Vol. 03, Issue 4, ISSN: 231 1784, pp. $606-616$.

[9] Ashwini K, (July - 2012), Problems and Prospects of Micro, Small and Medium Enterprises in India (With Special Reference to the state of Karnataka), Thesis submitted to Alagappa University, Tamil Nadu. 
[10] B. Deevana Margaret, (April 1994) "Problems and Prospects of Small scale Industries (Case Study of Anantapur District), thesis submitted to Department of Economic, Sri Kridhnadevaraya University, Anantapur.

[11] R. Sathru Sangara Velsamy, (Dec.2014 ), "The Problems and Prospects of Small Scale Industries in Pudukkottai District - A Critical Study", thesis submitted.

[12] Siddiq.I, (June 2013), "Service Quality of Public Sector Banks To MSME Entrepreneurs", thesis submitted to the Bharathiar University, Coimbatore. 